\title{
WET-EcoServices Version 2: A revised ecosystem services assessment technique, and its application to selected wetland and riparian areas
}

\author{
DC Kotze', DM Macfarlane'2, RJ Edwards² and B Madikizela ${ }^{3}$ \\ 'Centre for Water Resources Research, University of KwaZulu-Natal, Pietermaritzburg, \\ Private Bag X01, Scottsville, 3209, South Africa \\ ${ }^{2}$ Eco-Pulse Environmental Consulting Services, 26 Mallory Road, Hilton, 3245, South Africa \\ ${ }^{3}$ Water Research Commission, Private Bag X03, Gezina, 0031, South Africa
}

A rapid assessment technique, termed WET-EcoServices, was developed 10 years ago to help assess the ecosystem services that individual wetland hydrogeomorphic units supply. The technique requires the assessor to consider and score a suite of indicators (e.g., hydraulic roughness of the vegetation) which are then used to rate the ability of the wetland to provide 16 different ecosystem services. WET-EcoServices has become well entrenched in the South African context, with wetland specialists routinely using the technique to inform development planning, whilst it has also been used extensively in the wetland rehabilitation context. The technique has recently been revised, including the following key changes: (i) the technique is now more explicit in terms of distinguishing both ecosystem services' supply and the demand for all ecosystem services assessed; (ii) the technique has been expanded to include non-wetland riparian areas; (iii) several of the indicators have been refined or replaced with indicators more relevant or appropriate for informing the rating of the ecosystem service or for which information is more readily available at a national level; and (iv) the algorithms used to integrate scores for the relevant indicators have been comprehensively refined so as to better account for the relative importance of the respective indicators.

The aim of this paper is to present an overview of Version 2 of the technique and its underlying approach and then to demonstrate its application to 6 selected cases representing contrasting contexts, with a particular focus on the graphical representation of ecosystem service supply and demand for each case. Some of the key emphases and approaches applied by WET-EcoServices are then discussed in relation to other published techniques widely used for assessing wetland ecosystem services. After reflecting on some key limitations of WET-EcoServices, the paper concludes with recommendations on the technique's potential contributions to operationalizing key broad imperatives of government.

\section{CORRESPONDENCE}

DC Kotze

\section{EMAIL}

KotzeD@ukzn.ac.za

\section{DATES}

Received: 17 February 2020

Accepted: 18 August 2020

\section{KEYWORDS}

wetland

riparian area

rapid assessment

ecosystem services supply and demand

\section{COPYRIGHT}

() The Author(s)

Published under a Creative

Commons Attribution 4.0

International Licence

(CC BY 4.0)

\section{INTRODUCTION}

Wetlands are globally threatened and important ecosystems that provide multiple services to society (MEA, 2005; TEEB, 2010). The term 'wetland' refers to land which is transitional between terrestrial and aquatic systems where the water table is usually at or near the surface, or land which is periodically covered with shallow water, and which under normal circumstances supports or would support vegetation typically adapted to life in saturated soil, according to the South African National Water Act (Act No. 36 of 1998; RSA, 1998). Riparian areas, likewise, are also threatened and well-recognized for the ecosystem services which they supply (NRC, 2002; Capon and Pettit, 2018). 'Riparian habitat' encompasses the physical structure and vegetation of areas associated with a watercourse which are commonly characterised by alluvial soils, and which are inundated or flooded to an extent and with a frequency sufficient to support vegetation with a species composition and physical structure distinct from those of adjacent land areas (RSA, 1998).

Wetlands and riparian areas represent key ecological infrastructure, i.e., ecosystems with at least some of their ecological processes intact and the potential to complement built infrastructure (SANBI, 2013), with the prospect of contributing to several broad imperatives/objectives of South Africa's government. These include: water resource management; biodiversity conservation; human safety and disaster resilience; socio-economic development and poverty elimination; and climate change mitigation and adaptation.

The Millennium Ecosystem Assessment (2005) defines ecosystem services as the benefits people obtain from ecosystems. This was subsequently refined to refer to 'the aspects of ecosystems utilized (actively or passively) to produce human well-being' (Fisher et al., 2009 p. 645). Defined this way, ecosystem services include 'ecosystem organization or structure as well as process and/or functions if they are consumed or utilized by humanity either directly or indirectly' (Fisher et al., 2009 p. 645). Different categories of ecosystem services are recognized, with the most widely used categorization being the MEA (2005) categorization of supporting services, regulating services, provisioning services and cultural services, although it is increasingly recognized that these categories overlap, especially supporting and regulating services (IPBES, 2017).

Individual wetland/riparian areas differ according to their physical and ecological characteristics and the degree to which they supply different ecosystem services to society, as well as differing according 
to the context in which they are located and the level to which they contribute to social needs. Thus, there is a need to assess and compare wetland/riparian areas in terms of ecosystem services delivery to inform decision making. Recognizing this need, as well as the need within a country to standardize assessments for comparability and consistency in decision making, the first version of WET-EcoServices (Kotze et al., 2008) was developed. While at the time, several different techniques existed for assessing ecosystem services, none of these were directly transferable to the South African situation. Many of the techniques were geared primarily for the developed world and mainly for wetlands in northern temperate regions, and thus a locally relevant technique was developed. The first version has since been applied fairly widely within South Africa as well as further afield, mainly in other African countries (Namaalwa et al., 2013; Rebelo et al., 2013; Sullivan et al., 2008; Cowden et al., 2014; Kotze et al., 2018). Nevertheless, since the technique was first developed, the understanding of how wetlands and riparian areas function and supply services to society has advanced (e.g. see Capon and Pettit, 2018) and a range of new datasets relevant to ecosystem services have also become available in South Africa. In addition, many lessons have been learnt through the wide application of the technique for a diversity of purposes, providing 'fertile ground' for identifying specific improvements to the method. Furthermore, new techniques have been developed internationally, e.g., that of Hruby et al. (2011) and McInnes and Everard (2017), from which further lessons could be drawn. Thus, the first version of WETEcoServices (Kotze et al., 2008) has now been refined and revised to produce WET-EcoServices Version 2 (Kotze et al., 2020).

The aim of this paper is to present an overview of Version 2 of the technique and its underlying approach and then to demonstrate its application to selected cases which illustrate the variability in ecosystem service supply and demand in contrasting contexts.

\section{Key refinements undertaken to Version 1 of the technique}

The process of refining WET-EcoServices, which is described in detail in Kotze et al. (2020), began with soliciting comment on Version 1 and reviewing international best practice, which informed the development of an initial draft, which was applied and tested across a variety of wetlands and riparian areas. The testing included: (i) assessing the consistency of the results when applied by different assessors; and (ii) validation testing based on a comparison of the WET-EcoServices scores against the scores produced by an independent panel of experts who scored the sites based on detailed information which was available for the sites. Arising out of the refinement process were several key changes which were made to the technique (Table 1).

Table 1. A summary of the key refinements and additions made to Version 1 of WET-EcoServices in order to produce Version 2 (modified from Kotze et al., 2020)

Key refinements
Non-wetland riparian areas have been included
For all of the services assessed, supply and demand
are assessed separately and the beneficiaries of
the services are noted, in particular the level of
dependency of the beneficiaries on the services
being assessed

Addition of new indicators

Modification or replacement of some existing indicators

Deletion of some indicators

Improvements to ease the use of the technique

Refinements to the algorithms used to determine the scores for each ecosystem service based on the relevant indicator scores

Scores for supply and demand are calculated separately before integrating into an overall importance score

Guidance for calculating wetland offsets, which refer to outcomes designed to compensate for adverse impacts to wetland functions, services and biodiversity arising from project development, and generally designed to achieve at least a no-nettloss of ecosystem condition, biodiversity value and ecosystem services supply.

The addition of recommendations for scoring overall Ecological Importance and Sensitivity (EIS)
Reason for the change/addition

Extensive watercourses are non-wetland, supporting riparian habitat, which often provide important ecosystem services (NRC, 2002; Capon and Pettit, 2018).

To understand the full potential that wetlands/riparian areas have for delivering ecosystem services, both supply (the capacity of an ecosystem to produce a service) and demand (the societal demand for a service) must be individually considered (Wei et al., 2017; Bengtsson et al., 2019). Demand for an ecosystem service can change independently of its supply, and supply can change without altering demand (Bengtsson et al., 2019). Thus, for well-informed decisionmaking it is important that all ecosystem services be represented in terms of both supply and demand (Boerema et al., 2017). In many cases, supply of a particular service may be very high but demand may be very low, and vice versa. Considering the relative importance of supply and demand for each ecosystem service helps inform the identification of specific management threats and opportunities. An approximate estimate of the number of users and their dependency has further relevance to management.

A range of new indicators were included to account for the broadened scope of the assessment and to improve the accuracy of the assessment.

Some of the indicators were refined to better account for riparian areas, integrate new knowledge and improve the ease of use and repeatability of the method. A number of the indicators have also been replaced with indicators more relevant or appropriate for informing the rating of the ecosystem service or for which information is more readily available at a national level than the previous indicator.

These indicators, included in Version 1, were deleted for a variety of reasons, e.g., they were found to require information too detailed for a rapid assessment. Kotze et al. (2020) provides a full description of all deleted indicators and the rationale for their deletion.

A new and more user-friendly spreadsheet tool was developed which now includes the ability to assess a wetland/riparian area under different scenarios (e.g. with or without rehabilitation). Fuller explanations and illustrative examples were also provided to help guide the rating of indicators.

In Version 1, the scores for each ecosystem service were generally based on an algorithm comprising a simple average of the scores for the relevant indicators. However, in Version 2, the algorithms have been refined in an attempt to reflect the relative importance and interactions of the attributes represented by the indicators through the weighting and grouping of the indicators. The rationale and approach to integrating indicator scores was also documented to help users interrogate scores.

In Version 1 inadequate account was taken of the relative contributions of supply and demand in calculating an overall importance score.

Guidelines for wetland offsets were recently developed for the South African context (SANBI and DWS, 2016). This includes an emphasis on the functional values provided by wetlands to support water resource management. Specific guidance was therefore provided on how WETEcoServices could be used to better inform offset calculations.

The existing guidance for wetland EIS determination was somewhat limited and specific guidance lacking in terms of how to integrate findings from a more detailed Wet-EcoServices assessment if available. 


\section{An overview of WET-EcoServices Version 2}

WET-EcoServices Version 2 includes the assessment of 16 different ecosystem services (Table 2) which were selected for their specific relevance to the South African situation and which, according to the categorization of ecosystem services by MEA (2005), encompass supporting services, regulating services, provisioning services and cultural services. The technique has been designed for application to all inland wetlands and non-wetland riparian areas, but not to estuaries or the instream component of rivers.

As was the case for Version 1, WET-EcoServices Version 2 is specifically designed for rapid field assessment, defined as taking no more than 2 people a half day in the field and requiring no more than a half-day of office preparation and data analysis (Fennessy et al., 2004). An Excel-based spreadsheet tool (https:// www.eco-pulse.co.za/download) has been developed which is completed by rating a suite of indicators on a 5-point scale from 0 to 4 . Indicators are classified as 'desktop', 'desktop with field verification' or 'field-based' to facilitate scoring. Detailed guidance for scoring each indicator is provided in the accompanying Water Research Commission report of Kotze et al. (2020). Applying WET-EcoServices Version 2 encompasses 7 primary steps (from Kotze et al., 2020):

Step 1. Define the objectives and scope of the assessment, based on, amongst others, the following key questions: How will the importance scores be used? What specific decisions are to be informed? What are the specific information needs for these decisions?
Step 2. Identify the 'Assessment Unit/s' and their catchment/s and downstream service area/s. The Assessment Units within the mapped wetland/riparian area/s are identified by dividing these areas into 'Hydrogeomorphic (HGM) Units' - each HGM unit would generally constitute a separate assessment unit, but in some cases may be sub-divided or grouped together.

Step 3. Prepare before going into the field. This involves becoming familiar with all of the indicators and knowing which can be scored based on a desktop assessment and which need to be assessed in the field and then planning the field visit.

Step 4. Assess and score the indicators. All indicators need to be assessed and scored. For each indicator, the 'Rationale' underlying the indicator, and the 'Methods' which should be used to assess the indicator and decide on the score, are provided. It is important that the rationale provided be understood and that the methods be followed closely in order to promote consistency of assessment.

Step 5. Enter the scores in the spreadsheet. This is done on the first sheet of the spreadsheet, and the scores are then automatically carried through to the second sheet, where the calculations are made automatically via various algorithms.

Step 6. Check and where necessary refine the 'Demand' and 'Supply' scores. A 'Demand \& Supply' tab is used to integrate the scores for relevant indicators into a demand and supply score for each ecosystem service. These scores should be reviewed, and where they are identified to poorly reflect the situation on the ground can be adjusted, provided that well documented justification is given.

Table 2. Ecosystem services included in WET-EcoServices Version 2 (modified from Kotze et al., 2020)

\begin{tabular}{|c|c|c|c|c|}
\hline \multirow{8}{*}{ 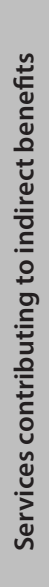 } & \multirow{8}{*}{ 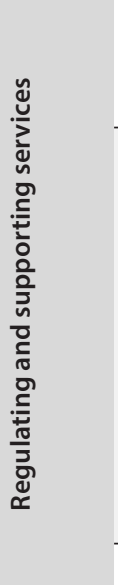 } & \multirow{2}{*}{\multicolumn{2}{|c|}{$\begin{array}{l}\text { Flood attenuation } \\
\text { Streamflow regulation }\end{array}$}} & The spreading out and slowing down of floodwaters in the wetland/riparian area, thereby \\
\hline & & & & Sustaining streamflow during low-flow periods \\
\hline & & \multirow{5}{*}{ 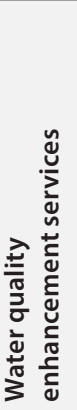 } & Sediment trapping & The trapping and retention in the wetland/riparian area of sediment carried by runoff water \\
\hline & & & Phosphate assimilation & $\begin{array}{l}\text { Removal by the wetland/riparian area of phosphates carried by runoff water, thereby } \\
\text { enhancing water quality }\end{array}$ \\
\hline & & & Nitrate assimilation & $\begin{array}{l}\text { Removal by the wetland/riparian area of nitrates carried by runoff water, thereby enhancing } \\
\text { water quality }\end{array}$ \\
\hline & & & $\begin{array}{l}\text { Toxicant \& pathogen } \\
\text { assimilation }\end{array}$ & $\begin{array}{l}\text { Removal by the wetland/riparian area of toxicants (e.g. metals, biocides, salts) and } \\
\text { pathogens carried by runoff water, thereby enhancing water quality }\end{array}$ \\
\hline & & & Erosion control & $\begin{array}{l}\text { Controlling erosion within the wetland/riparian area, principally through the protection } \\
\text { provided by vegetation }\end{array}$ \\
\hline & & \multicolumn{2}{|c|}{ Carbon storage } & The trapping of carbon by the wetland/riparian area, principally as soil organic matter \\
\hline \multirow{8}{*}{ 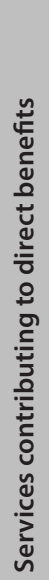 } & \multicolumn{3}{|c|}{ Biodiversity maintenance ${ }^{1}$} & $\begin{array}{l}\text { Through the provision of habitat and maintenance of natural processes by the wetland/ } \\
\text { riparian area, a contribution is made to maintaining biodiversity }\end{array}$ \\
\hline & \multirow{4}{*}{ 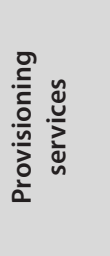 } & \multicolumn{2}{|c|}{$\begin{array}{l}\text { Provision of water for human } \\
\text { use }\end{array}$} & $\begin{array}{l}\text { The provision of water which is taken directly from the wetland/riparian area for domestic, } \\
\text { agricultural or other purposes }\end{array}$ \\
\hline & & \multicolumn{2}{|c|}{$\begin{array}{l}\text { Provision of harvestable } \\
\text { resources }\end{array}$} & $\begin{array}{l}\text { The provision of natural resources from the wetland/riparian area - including craft plants, } \\
\text { fish, wood, etc. }\end{array}$ \\
\hline & & \multicolumn{2}{|c|}{ Food for livestock } & The provision of grazing for livestock \\
\hline & & \multicolumn{2}{|c|}{ Provision of cultivated foods } & The provision of cultivated foods from within the wetland/riparian area \\
\hline & \multirow{3}{*}{ 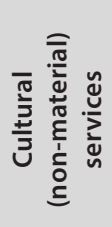 } & \multicolumn{2}{|c|}{$\begin{array}{l}\text { Cultural and spiritual } \\
\text { experience }\end{array}$} & $\begin{array}{l}\text { Places of special cultural significance in the wetland/riparian area - e.g. for baptisms or } \\
\text { gathering of culturally significant plants }\end{array}$ \\
\hline & & \multicolumn{2}{|c|}{ Tourism and recreation } & $\begin{array}{l}\text { Sites of value for tourism and recreation in the wetland/riparian area, often associated with } \\
\text { scenic beauty and abundant birdlife }{ }^{2}\end{array}$ \\
\hline & & \multicolumn{2}{|c|}{ Education and research } & Sites of value in the wetland/riparian area for education or research \\
\hline
\end{tabular}

'It is recognized that biodiversity maintenance is not an ecosystem service in the strict sense (Liquete et al. 2016), and is framed in less anthropocentric terms than all of the other services, but it underpins many other services and is widely acknowledged as having high value to society broadly, even in the absence of any local or downstream beneficiaries.

${ }^{2}$ WET-EcoServices focuses on recreational services which are specifically nature-based, e.g., bird watching. It does not account specifically for recreational services from wetland/riparian areas that have been converted into sports grounds, children's playgrounds or other built infrastructure. 
Step 7. Present and interpret the results. These are presented as a summary table showing the supply, demand and overall importance scores for each ecosystem service and as a spider diagram showing supply and demand. Guidance is provided in terms of interpreting supply relative to demand.

For each ecosystem service, indicator scores are combined automatically in the spreadsheet using algorithms that have been designed to reflect the relative importance and interactions of the attributes represented by the indicators to arrive at an overall supply and demand score. This automation is based on a conceptual understanding of the relative importance of different indicators in influencing the supply of and demand for each ecosystem service, informed by the literature as well as the expert interpretation of the authors. The supply and demand algorithms are not hidden in a 'black box' and can be viewed by the user, who is also provided with a written rationale for the relative importance accorded different indicators, and how some might interact. For illustrative purposes, two services, namely flood attenuation and tourism and recreation, are described below in terms of the rationale behind the algorithms developed for their respective supply and demand. An outline of how the various individual indicators have been weighted to provide a composite final score for supply and demand, respectively, is also provided.

\section{Rationale for the relative importance accorded different indicators: Flood attenuation}

The supply of the flood attenuation service is affected by both: (i) the 'Assessment Unit' setting and catchment context; and (ii) on-site (local) attributes of the Assessment Unit. The catchment context is affected by two indicators: the size of the Assessment Unit's catchment and whether the assessment unit is linked to the stream network. Given the emphasis on benefits of flood attenuation to downstream users, this assessment is only relevant to assessment units that are directly linked to the stream network. As such, the supply score is taken as zero if there is no connection. If the upstream catchment feeding a wetland or riparian area is large (as is the case with most floodplains) then the land surface is great over which floodwaters accumulate and are ultimately 'delivered' to the downstream users. In contrast, if the upstream catchment is small (as is typical of hillslope seepage wetlands) then this land area over which floodwaters accumulate is small. As such, wetlands and riparian areas with the largest catchments receive the highest starting supply scores, whilst those with the smallest contributing catchments score lowest.

By far the most influential on-site indicator affecting flood attenuation, is the frequency with which stormflows are spread across the surface of the assessment unit. If this does not occur or is very infrequent then all of the other on-site indicators, which reflect the surface attributes of the assessment unit, will have little influence over floods. Thus, this influential indicator is used as the initial score and is adjusted by the average of the three highest scores for the other on-site indicators of the unit, namely, slope, representation of different hydrological zones, occurrence of depressions, soil permeability, and vegetation structure in terms of height and robustness.

The demand for flood attenuation is based on: (i) an assessment of 'at risk' users located downstream of the assessment unit and (ii) an assessment of flooding risks stemming from the catchment directly upstream of the assessment unit. A starting demand score is calculated from an assessment of potential beneficiaries downstream, based on indicators reflecting the number of people downstream expected to be affected by flooding, and a further indicator reflecting the level of risk that flooding poses to these people. This starting demand score is then automatically adjusted by also considering the intensity of runoff from the assessment unit's catchment. The latter is based on indicators reflecting the inherent runoff potential of the catchment (slope, runoff potential of the soils, and rainfall intensity) and indicators reflecting the human influence over runoff intensity (contribution of catchment land-uses, such as hardened surfaces, to increasing runoff intensity, and interception of flows by upstream dams).

\section{Rationale for the relative importance accorded different indicators: Tourism and recreation}

Assessing the supply of the tourism and recreation service recognizes that a wide variety of natural assets may attract people to wetland/riparian areas for tourism/recreation. In addition, the suitability of a site for tourism and recreation is influenced by access and security. To account for this interaction, the supply score is initially calculated by averaging the top two scores for the following five indicators: recreational hunting, fishing and birding opportunities, presence of charismatic species, scenic beauty, extent of open water, and outstanding biodiversity attributes. This score is then down-weighted based on the two indicators reflecting limitations associated with access and security risk, respectively. The demand for tourism and recreation is affected by the number of people who access the wetland/riparian area for tourism/ recreation on an annual basis and the dependence of these users on the specific Assessment Unit for tourism/recreation. A key factor affecting dependence is the availability of alternative areas providing similar tourism/recreational experiences to the site.

Once supply and demand scores have been calculated, a single overall importance score is generated for each ecosystem service by combining the supply and demand scores. This aggregation places somewhat more emphasis on supply than demand. However, assessors are encouraged not to focus on the overall score (or importance category) alone as this will result in the 'loss' of useful information.

Specific recommendations are also provided for integrating the WET-EcoServices outputs into the assessment of wetland 'Ecological Importance and Sensitivity' (EIS), which is a term well entrenched in water resource management in South Africa. 'Ecological Importance' (EI) is the expression of the importance of wetlands and rivers in terms of their maintenance of biological diversity and ecological functioning (Rountree et al., 2013). The EIS recommendations provided include grouping of ecosystem service scores into the following broad categories, which would then be integrated into an overall ecological importance (EI) score: (i) biodiversity maintenance importance, derived from the biodiversity maintenance component of WET-EcoServices; (ii) regulating services importance, from the importance scores for regulating services considered in WET-EcoServices; and (iii) provisioning and cultural services importance, from the importance scores for provisioning and cultural services considered in WET-EcoServices. A single overall EI score can then be derived based on the maximum of these three scores and could then be integrated with the ecological sensitivity (ES) score to produce an overall EIS score.

Finally, guidance is provided on how the WET-EcoServices technique can be applied in wetland offset calculations. This has particular relevance to assessments concerned with the impact of wetland loss and the consequent loss of wetland services relevant to water resource management, disaster risk management and climate resilience and adaptation. The approach allows for an offset currency to be developed based on the local catchment context and uses a hectare equivalents approach to quantify residual impacts associated with developments and to quantify the gains in response to rehabilitation actions. The application of WET-EcoServices in offset planning is not covered any further in this paper, but is described in detail in Kotze et al. (2020). 


\section{APPLICATION OF THE TECHNIQUE TO SELECTED CASES}

\section{Purpose of the case study assessments}

The purpose of these case studies (three in total) is to illustrate the application of WET-EcoServices Version 2 by using the technique to compare and contrast ecosystem services provided by a diversity of wetland and riparian areas. Within each case study a comparison is made between two Assessment Units which are situated in the same catchment. Thereafter, a brief comparison is made across all six sites in order to better understand how landuse context might affect the supply and demand of ecosystem services. The first case study comprises two wetland Assessment Units in the same local catchment in the Manalana (Craigieburn) area of Bushbuckridge, Limpopo Province, which is characterised by a communal agricultural context. The second case study contrasts two wetland Assessment Units which form part of the Kromme River wetland, Eastern Cape, which is situated in a commercial agricultural context. Lastly, the third comparison is between two non-wetland riparian areas in the lower uMdloti River catchment, KwaZulu-Natal, both located within a sugarcane production and urban context.

\section{Background information on the six case sites}

The Assessment Units encompass a diversity of HGM types and land-uses (Table 3). The Manalana HGM 1 and Manalana HGM 2 are similar in terms of land-cover and land-use, with both subject to a high intensity of human use but differ with respect to HGM type and hydrological zonation (Table 3). Similarly, Kromme Upper and Kromme Lower Assessment Units are similar in terms of land-cover and land-use but differ with respect to HGM type, hydrological zonation and sediment type (Table 3 ). The uMdloti River Riparian Units 1 and 2, both have highly developed catchments, but represent contrasting types in terms of stream order and hydro-geomorphic characteristics (Table 3 ).

Table 3. The six sites (Assessment Units) to which WET-EcoServices was applied

\begin{tabular}{|c|c|c|c|c|c|c|}
\hline $\begin{array}{l}\text { Assessment } \\
\text { Unit }\end{array}$ & HGM type/s & $\begin{array}{l}\text { Hydrological } \\
\text { zonation }\end{array}$ & Sediment type/s & Vegetation & $\begin{array}{l}\text { Land-use in the } \\
\text { wetland }\end{array}$ & $\begin{array}{l}\text { Land-use in the } \\
\text { wetland's catchment }\end{array}$ \\
\hline $\begin{array}{l}\text { Manalana } \\
\text { HGM } 1 \\
24^{\circ} 40^{\prime} 2.76^{\prime \prime} \mathrm{S} \\
30^{\circ} 58^{\prime} 30.88^{\prime \prime} \mathrm{E}\end{array}$ & $\begin{array}{l}\text { Hillslope seep } \\
\text { with a high } \\
\text { level of lateral } \\
\text { input as } \\
\text { interflow }\end{array}$ & $\begin{array}{l}\text { Predominantly } \\
\text { temporarily } \\
\text { saturated }\end{array}$ & $\begin{array}{l}\text { Mineral: sandy } \\
\text { sediments with } \\
\text { clay lenses and } \\
\text { a clay 'plug' at } \\
\text { the outlet of the } \\
\text { wetland }\end{array}$ & $\begin{array}{l}\text { Natural/semi- } \\
\text { natural areas } \\
\text { dominated } \\
\text { by Phragmites } \\
\text { mauritianus reeds } \\
\text { and the grass } \\
\text { Imperata cylindrica }\end{array}$ & $\begin{array}{l}\text { A mosaic of small- } \\
\text { scale cultivated } \\
\text { plots and natural/ } \\
\text { semi-natural areas }\end{array}$ & $\begin{array}{l}\text { A mosaic of small- } \\
\text { scale cultivated plots, } \\
\text { homesteads, roads/ } \\
\text { tracks, eroded areas } \\
\text { and natural/semi- } \\
\text { natural areas }\end{array}$ \\
\hline $\begin{array}{l}\text { Manalana } \\
\text { HGM } 2 \\
24^{\circ} 40^{\prime} 5.15^{\prime \prime} \mathrm{S} \\
30^{\circ} 58^{\prime} 56.02^{\prime \prime} \mathrm{E}\end{array}$ & $\begin{array}{l}\text { Unchannelled } \\
\text { valley bottom }\end{array}$ & $\begin{array}{l}\text { Predominantly } \\
\text { seasonally } \\
\text { saturated }\end{array}$ & $\begin{array}{l}\text { Mineral: sandy } \\
\text { sediments with } \\
\text { clay lenses }\end{array}$ & $\begin{array}{l}\text { Vegetation as } \\
\text { above but with } \\
\text { the sedges } \\
\text { Schoenoplectus } \\
\text { brachyceras, Pycreus } \\
\text { mundii, and Cyperus } \\
\text { latifolius in the } \\
\text { wettest portions }\end{array}$ & As above & As above \\
\hline $\begin{array}{l}\text { Kromme River } \\
\text { Upper HGM unit } \\
33^{\circ} 52^{\prime} 34.98^{\prime \prime} S \\
24^{\circ} 2^{\prime} 58.01^{\prime \prime} \mathrm{E}\end{array}$ & $\begin{array}{l}\text { Weakly } \\
\text { channelled } \\
\text { valley bottom }\end{array}$ & $\begin{array}{l}\text { Predominantly } \\
\text { permanently } \\
\text { saturated }\end{array}$ & $\begin{array}{l}\text { Organic sediment } \\
\text { with coarse sandy } \\
\text { lenses }\end{array}$ & $\begin{array}{l}\text { Predominantly } \\
\text { natural vegetation } \\
\text { dominated by } \\
\text { extensive beds of } \\
\text { Palmiet (Prionium } \\
\text { serratum) }\end{array}$ & $\begin{array}{l}\text { Predominantly } \\
\text { natural vegetation }\end{array}$ & $\begin{array}{l}\text { Predominantly } \\
\text { natural vegetation } \\
\text { but with pasture for } \\
\text { the dairy and meat } \\
\text { industries and limited } \\
\text { orchards, particularly } \\
\text { on the lowlands } \\
\text { adjacent to the unit }\end{array}$ \\
\hline $\begin{array}{l}\text { Kromme River } \\
\text { Lower HGM unit } \\
33^{\circ} 54^{\prime} 50.26^{\prime \prime} \mathrm{S} \\
24^{\circ} 11^{\prime} 38.48^{\prime \prime} \mathrm{E}\end{array}$ & $\begin{array}{l}\text { Channelled } \\
\text { valley bottom }\end{array}$ & $\begin{array}{l}\text { Predominantly } \\
\text { seasonally } \\
\text { saturated }\end{array}$ & $\begin{array}{l}\text { Extensive } \\
\text { deposition of very } \\
\text { coarse sand over } \\
\text { the unit occurred } \\
\text { in 2012, burying } \\
\text { somewhat finer } \\
\text { sand and silt } \\
\text { beneath }\end{array}$ & $\begin{array}{l}\text { Predominantly } \\
\text { natural vegetation } \\
\text { comprising a } \\
\text { mosaic of small } \\
\text { Prionum serratum } \\
\text { patches, mixed } \\
\text { sedges/grasses/ } \\
\text { shrubs and open } \\
\text { sandy patches }\end{array}$ & $\begin{array}{l}\text { As above, but } \\
\text { noting that while } \\
\text { this HGM unit } \\
\text { is still relatively } \\
\text { natural, it forms } \\
\text { part of a larger } \\
\text { wetland area that } \\
\text { includes extensive } \\
\text { transformation } \\
\text { (see main text) }\end{array}$ & $\begin{array}{l}\text { As above for the } \\
\text { overall catchment, } \\
\text { but intensive } \\
\text { pastures are located } \\
\text { immediately } \\
\text { upstream of and } \\
\text { adjacent to the HGM } \\
\text { unit }\end{array}$ \\
\hline $\begin{array}{l}\text { Mdloti River } \\
\text { Riparian Unit } 1 \\
29^{\circ} 38^{\prime} 44.0^{\prime \prime S} \\
31^{\circ} 06^{\prime} 12.77^{\prime \prime} \mathrm{E}\end{array}$ & Flood bench & Non-wetland & $\begin{array}{l}\text { Well-drained } \\
\text { alluvium }\end{array}$ & $\begin{array}{l}\text { Dense mix of } \\
\text { indigenous } \\
\text { herbaceous and } \\
\text { woody vegetation } \\
\text { with moderate } \\
\text { levels of alien } \\
\text { invasive plant } \\
\text { invasion }\end{array}$ & $\begin{array}{l}\text { Mix of natural / } \\
\text { indigenous and } \\
\text { alien invasive } \\
\text { vegetation }\end{array}$ & $\begin{array}{l}\text { Intensive sugarcane } \\
\text { agriculture, dense } \\
\text { urban areas, peri- } \\
\text { urban areas and rural } \\
\text { areas }\end{array}$ \\
\hline $\begin{array}{l}\text { Mdloti River } \\
\text { Riparian Unit } 2 \\
29^{\circ} 37^{\prime} 50.45^{\prime \prime S} \\
31^{\circ} 04^{\prime} 25.51^{\prime \prime} \mathrm{E}\end{array}$ & $\begin{array}{l}\text { Steep bank } \\
\text { that forms part } \\
\text { of the active } \\
\text { channel of a } \\
1^{\text {st }} / 2^{\text {nd }} \text { order } \\
\text { ephemeral } \\
\text { stream }\end{array}$ & Non-wetland & Clay loam & $\begin{array}{l}\text { Wholly dominated } \\
\text { by alien invasive } \\
\text { plant species, both } \\
\text { herbaceous and } \\
\text { woody }\end{array}$ & $\begin{array}{l}\text { Alien invasive } \\
\text { vegetation } \\
\text { with intensive } \\
\text { sugarcane } \\
\text { cultivation along } \\
\text { edges }\end{array}$ & $\begin{array}{l}\text { Intensive sugarcane } \\
\text { agriculture }\end{array}$ \\
\hline
\end{tabular}


In Manalana HGM 1, low flows would naturally have occurred mainly as sub-surface seepage and some diffuse surface flow. However, the creation of extensive raised beds for cultivation across most of the HGM unit has concentrated low flows, although less so where several of these beds have been abandoned. In Manalana HGM 2, as for HGM 1, much of the unit has been cultivated and converted to raised beds which concentrate low flows. However, most of the beds continue to be cultivated but the channels between the beds support dense growth of indigenous hydrophytic species.

The Kromme Upper HGM unit is dominated by tall ( $3 \mathrm{~m})$ and robust Palmiet (Prionium serratum), underlain by organic sediment and characterized by relatively diffuse flows through the unit. Headward erosion by a large gully at the foot of the eastern portion has been halted with a large erosion-control gabion weir. The Kromme Lower HGM unit is located $17.5 \mathrm{~km}$ downstream of the Kromme Upper unit and is characterized by markedly less diffuse flow and is underlain by mineral sediment. The Kromme Lower HGM unit comprises an area of natural/ semi-natural vegetation within a larger wetland area that includes areas transformed to planted pastures both upstream and adjacent to the HGM unit. For the purposes of this case study, the unit of assessment is defined as the area of the wetland covered by natural/semi-natural vegetation, with the adjacent and upstream transformed wetland taken as a key part of the unit's influencing catchment, e.g., as a source of nitrates from applied fertilizers. Shortly after a major storm in 2012, most of the Kromme Lower unit became covered in bare sand, transported from upstream and deposited in the unit. Nevertheless, by 2017 much of these bare areas had become colonized by vegetation, with some bare areas still remaining and comprising a smaller proportion of the cover within the assessment unit. In contrast, the Kromme Upper unit maintained complete vegetation cover throughout the period between 2012 and 2017.

The two uMdloti River riparian units represent opposite ends of the spectrum of typical riparian fluvial geomorphic forms. Unit 1 comprises a series of low-lying, gently sloping and relatively broad alluvial flood benches of the lower uMdloti River and is about $3 \mathrm{~km}$ upstream of the uMdloti River mouth. Unit 2 is located along a steeply sloping, low-order tributary stream with an incised active channel, and is upstream of the nationally important Lake Victoria Wetland.

\section{Comparison of the WET-EcoServices assessments for the six sites}

The spider diagram summaries of ecosystem service supply and demand for the six sites are given in Fig. 1, and key trends which are revealed in these diagrams are discussed.

\section{A comparison of the two Manalana HGM sites}

A comparison of Manalana HGM 1 and 2 shows generally similar patterns in terms of supply and demand, but with four main differences. Firstly, there is a much higher supply and demand for harvestable natural resources and water supply in HGM 2 than in HGM 1. The higher level of wetness in HGM 2 supports extensive Schoenoplectus brachyceras sedges, which are sought after for craft production, and HGM 2 has a much more sustained discharge of sub-surface water, which is used for domestic purposes.

Secondly, demand for sediment trapping and water quality enhancement services are somewhat higher in HGM 2, given the greater extent of human settlements and erosion features in its catchment compared with HGM 1 . However, the supply of these services is fairly similar in both HGM units given their similar pattern of low flows, vegetation cover, etc., and the fact that both have been somewhat compromised by cultivation within the unit, although supply of nitrate assimilation in HGM 2 is slightly higher given the marginally more favourable level of wetness in this unit than in HGM 1.

Thirdly, the demand for cultivated foods relative to supply is higher in HGM 2 than in HGM 1. Fourthly, demand for erosion control is higher in HGM 2 than HGM 1, given the greater importance of the site for direct use, which would be compromised if major erosion were to take place.

Based on the four main differences described above, it can be appreciated that, overall, HGM 2 is more important than HGM 1 from an ecosystem services perspective. Therefore, within a context of limited resources, HGM 2 might be prioritized over HGM 1 for protection against further degradation, especially if supporting local livelihoods was a high priority.

\section{A comparison of the two Kromme units}

A comparison of the Kromme Lower and Upper units shows reasonably similar patterns in terms of provisioning services, most of which are fairly low in terms of both supply and demand, except for water supply. Both units also show a generally low demand for cultural services, but the upper unit scores higher in terms of supply of these services.

The greatest contrasts between the Lower and Upper units lie with the supply of regulating/supporting services. Firstly, all regulating/supporting services, with the exception of sediment trapping, scored higher for supply in the Upper than in the Lower unit. This is primarily owing to the Upper unit comprising a wellvegetated, intact Palmiet (Prionium serratum) bed, with low flows reasonably widely distributed through the unit, compared with the Lower unit which lacked the organic soils, and had lower vegetation cover and more confined flows.

Secondly, biodiversity maintenance scored very high in terms of demand in both units, in particular given that both represent a threatened wetland type, but in terms of supply, the Upper unit scored significantly higher, owing mainly to its ecological condition being much better than the Lower unit, and therefore representing the threatened type much better than the Lower unit.

Based on the main differences described above, it can be appreciated that, overall, the Upper unit is more important than the Lower unit from an ecosystem services perspective, particularly in terms of biodiversity maintenance and carbon storage. However, it is important to note that the Lower unit is very dynamic in terms of key parameters influencing ecosystem services supply, notably sediment deposition and vegetation cover, and its supply is likely to improve if vegetation cover continues to increase.

\section{A comparison of the two uMdloti River riparian units}

Unit 1 scored consistently higher than Unit 2 for the regulating and supporting ecosystem services, with flood attenuation, in particular, scoring markedly higher in Unit 1 than Unit 2 (Fig. 1). The higher supply scores for Unit 1 relative to Unit 2 is to be expected because of the larger catchment, the higher frequency of riparian zone flooding, the gentle lateral/cross-sectional slope and the higher roughness coefficient of the riparian vegetation. In the case of flood attenuation, the gentler longitudinal slope of Unit 1 is a further important influence on the supply score. In contrast to the supply scores for the regulating services, the demand scores were generally moderate to high for both units (Fig. 1), owing to the intense upstream catchment impacts and important downstream aquatic ecosystems present in both units.

Biodiversity maintenance supply and demand scores were considerably higher for Unit 1 compared to Unit 2, owing in 
particular to the riparian vegetation in Unit 1 being in much better ecological condition than in Unit 2, and Unit 1 being located within a provincial Critical Biodiversity Area (CBA), while Unit 2 did not fall in a CBA.

The supply and demand scores for the provisioning and cultural services provided by both units were similarly generally low but with a moderately high supply for cultivated food and harvestable resources (Fig. 1). Soil conditions are broadly suitable for dryland agriculture, and the moderately high supply scores for harvestable resources can be attributed primarily to the prevalence of a large number of trees that make up the majority of the riparian vegetation.

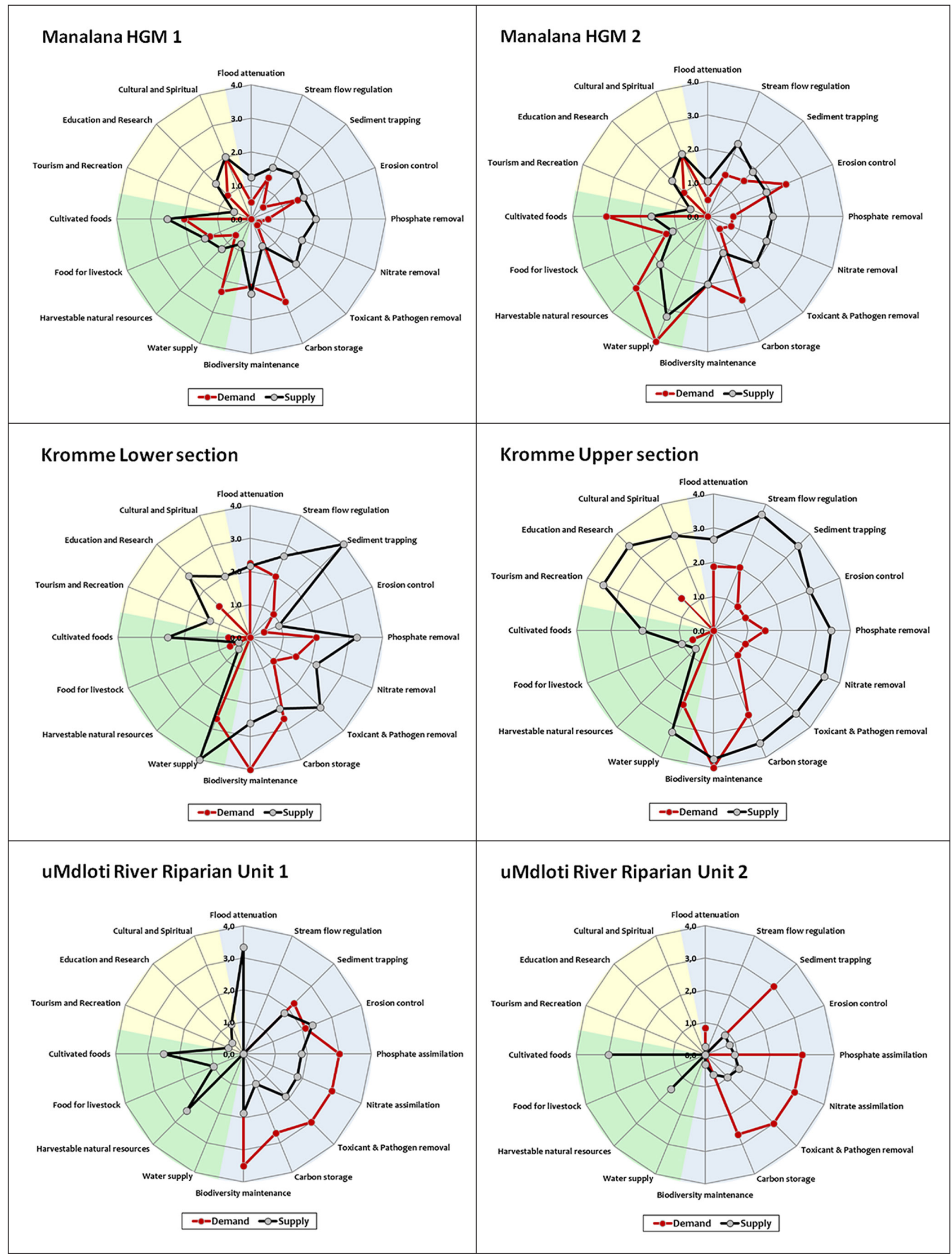

Figure 1. Summary of the supply and demand scores for the six assessed units 


\section{A brief overview across all six sites}

From an appraisal of the relative demand and supply of ecosystem services across all six sites in Fig. 1, several differences can be observed. It is evident that the Manalana units are considered to have a slightly higher level of importance associated with their provisioning services relative to their regulating services, which is commonly encountered in a communal rural context within South Africa. In contrast, for the Kromme units, regulating services are generally more important than provisioning services, with the exception of water supply. Demand for water quality enhancement services was rated as moderate in the two Kromme units, given the moderate extent of intensive agriculture in their catchment. Where intensive agriculture or urban development is more prevalent, then demand for regulating services is likely to be higher, which is demonstrated by the two uMdloti riparian units having a higher demand for regulating services (particularly water quality enhancement services). Another key difference between the six sites assessed, is the greater level of importance assigned to biodiversity maintenance of the Kromme sites and Mdloti Unit 1, in comparison to the Manalana sites and Mdloti Unit 2. Lastly, the Kromme Upper unit's biodiversity maintenance scores, are the only instance where both supply and demand scores were very close to their maximum possible scores. This emphasises the importance of this site for conserving intact and highly threatened biodiversity features.

\section{DISCUSSION AND CONCLUSIONS}

There is no such thing as an ideal wetland assessment technique, and the suitability of any technique depends on the particular wetland and the purpose of the assessment (Bartoldus, 1999). It is not surprising, therefore, that there are many different emphases and approaches amongst the various wetland ecosystem services assessment techniques that have been developed, depending on their respective purposes. In discussing some of the key emphases and approaches applied by WET-EcoServices, the technique will be compared against two other widely used and contrasting techniques. The first is that of Hruby et al. (2011), which was developed as a rapid technique used to improve wetland mitigation in the State of Washington, US. The second, the Rapid Assessment of Wetland Ecosystem Services (RAWES) method (McInnes and Everard, 2017), is designed for general purpose assessments, with applicability across all wetland types and includes a very large number (36) of different ecosystem services.

WET-EcoServices and the technique of Hruby et al. (2011) for Washington State both require an identification of HGM type and go into a similar level of detail in defining indicators and providing a rationale and supporting method for the indicators. In addition, the two techniques also score both ecosystem supply and demand separately, and these scores are derived from the relevant indicator scores using a prescribed algorithm. However, in the Washington State method, services/functions are grouped (into improving water quality, hydrologic functions, and wildlife habitat), while assessed as several separate ecosystem services by WET-EcoServices.

RAWES (McInnes and Everard, 2017) and WET-EcoServices are similar in being applicable across a wide range of wetland types. They also include several individual ecosystem services, such as: supporting, regulating and provisioning services, although RAWES includes slightly more than double the number of services overall, and both recommend using local knowledge and stakeholders as a key source of information.

A key difference between RAWES and WET-EcoServices is the 'level' at which the scoring takes place. In RAWES, a few qualitative indicators are listed for each ecosystem service, but a detailed description of the indicator (as provided by WETEcoServices and the Washington method) is lacking and the individual indicators are not scored. Instead, the technique relies on the assessor to consider the suggested indicators (and others deemed relevant) and score the ecosystem service based on his/ her gut feel 'opinion'. This contrasts with WET-EcoServices and the Washington method, where individual indicators are scored and these scores are aggregated based on a prescribed algorithm. WET-EcoServices does, however, allow the assessor to adjust this score based on identified factors not accounted for by the technique, provided that written justification is provided.

It is important to note that the three techniques compared and contrasted above are all designed for assessment at a fairly similar scale/resolution, namely, for rapid field-assessments. This is intermediate in a range from high-resolution field assessments (generally involving quantification of key ecological processes underpinning the ecosystem services) to low-resolution desktop assessments (often of multiple wetlands across catchments and landscapes). For these two extremes, WET-EcoServices is inappropriate. For high-resolution assessments, the technique does not give a detailed description of biogeochemical and hydrogeomorphic processes, but instead uses coarse-scale proxies of these processes. Thus, the technique cannot be used to make fine-resolution distinctions in terms of ecosystem services provision. Although the technique employs several indicators designed for desktop assessment, it does not provide a cost-effective means of assessing large numbers of wetlands at a landscape/catchment scale, for which desktop ecosystem services mapping methods such as ARIES - ARtificial Intelligence for Ecosystem Services (Villa et al., 2014) are more appropriate.

Some key further limitations of the WET-EcoServices technique include the following: (i) Scores obtained using the technique have not been correlated with real economic values, and as such, cannot be used to infer even relative economic values for the services provided by wetland or riparian areas. Furthermore, given that scores for each service are relative to other wetlands for a specific service, a high importance score for flood attenuation, for example, cannot be equated with a high importance score for livestock grazing. (ii) Demand for the ecosystem services takes into account the number of users very coarsely, with only a 5-class scale. In addition, the level of dependency of users does not represent the diversity of dependency which may exist amongst users, and also does not explicitly account for the multiple socioeconomic factors affecting dependency. (iii) Application and testing within non-wetland riparian ecosystems was limited, although initial application to a diversity of non-wetland riparian areas, such as the two uMdloti units included in this study, has been used to benchmark results across a suite of wetland and riparian areas. In addition, testing has been greater in the higher rainfall areas of the country than in semi-arid to arid areas, and no unvegetated wetlands were included in the testing.

The application of WET-EcoServices Version 2 at the six sites, and the refinements reported in Table 1, suggest that the usability and capability of the technique have been improved with Version 2, and a useful contribution has been made to standardizing ecosystem service assessments for comparability and consistency in decision making. However, from the limitations discussed above it can be seen that ecosystem service demand, in particular, is crudely accounted for, and further testing across a range of wetland and riparian types and land-use contexts is needed. WET-EcoServices allows the assessor to adjust the final scores, which has particular relevance to types and contexts for which there has been very little testing, and for atypical wetlands rarely encountered in the South Africa context. Documented justifications for any adjustments made, together with the fact that the technique retains a record 
of the original score (rather than over-writing it), will hopefully assist in identifying specific refinements required to the technique as it continues to be applied and refined in the future. An online platform is recommended for assessors to upload their results so that recurring issues can be identified, thereby contributing to future refinements of the technique.

The paper concludes by reflecting on the potential contribution of the technique to key broad-scale imperatives/objectives of government referred to in the introduction, namely: (i) water resource management; (ii) biodiversity conservation; (iii) human safety and disaster resilience; (iv) socio-economic development and poverty elimination; and (v) climate change mitigation and adaptation.

Briefly, WET-EcoServices Version 2 is seen to contribute to these respective imperatives as follows: (i) The technique has clear links to water resource management given that seven of the eight regulating services relate directly to water resource management and, in addition, water supply is included as a provisioning service, and all of these are explicitly assessed according to supply and demand. Furthermore, the EIS recommendations included in the technique are specifically tailored for the water use licensing and reserve determination processes under the National Water Act. (ii) The technique explicitly deals directly with the conservation of biodiversity through inclusion of biodiversity maintenance as one of the services assessed in the technique, and the technique also attempts to take account of national initiatives such as listing of threatened wetland types by the South African National Biodiversity Institute (SANBI). (iii) The technique includes flood attenuation and, given that floods are one of South Africa's key disaster types, it can be used to flag wetlands that play a particularly important role in ecosystem-based disaster risk reduction at a site level. (iv) The technique includes, but does not directly address, the issue of socio-economic development, but has a potentially useful contribution to make in highlighting at a scoping level the consequences of different development scenarios for the suite of services provided to society, and this contribution is further enhanced with the offsets determination module that was developed for Version 2. (v) The technique does not explicitly address climate change mitigation and adaptation, but it includes an assessment of relevant ecosystem services such as carbon storage, which has direct relevance to mitigation, and flood attenuation and erosion control, which are relevant to adaptation.

From the preceding discussion it can be seen that WETEcoServices Version 2 has potentially useful contributions to make to all of the imperatives/objectives of government examined above. Two of these, namely, maintenance of biodiversity and water resources management, are fairly explicitly dealt with, e.g., through EIS recommendations tailored for the water use licensing process. However, for the other three aspects (namely human safety and disaster resilience, socio-economic development and poverty elimination, and climate change mitigation and adaptation) specific guidance is lacking, and this would be useful to develop.

\section{ACKNOWLEDGEMENTS}

The Water Research Commission is gratefully acknowledged for funding the development of WET-EcoServices Version 2 and this paper. M Mander and C Pringle are acknowledged for detailed review and valuable suggestions for refinements to WETEcoServices Version 2. S Sibiya is thanked for the consistency testing of the technique and A Texeira-Leite, J Lagesse, B Mafela, Q Ndlazi, T Ngobela and D Ollis are thanked for their valuable feedback on earlier drafts of the technique, and the WRC Reference Group is gratefully acknowledged for their guidance. They included B Madikizela (Chair) J Jay; B Weston; L Matlala;
E Mogakabe; P Gola; D Lindley; C Pringle; R Grobler; P-L Grundling; W Malherbe and J Mulders. J Lagasse is thanked for her contributions to some of the cases and for proofreading this manuscript.

\section{REFERENCES}

BARTOLDUS CC (1999) A Comprehensive Review of Wetland Assessment Procedures: A Guide for Wetland Practitioners. Environmental Concern Inc., St. Michaels, MD.

BENGTSSON J, BULLOCK JE, EGOH B, EVERSON C, EVERSON T, O'CONNOR T, O'FARRELL PJ, SMITH HG and LINDBORG R (2019) Grasslands-more important for ecosystem services than you might think. Ecosphere. 10 (2) https://doi.org/10.1002/ecs2.2582

BOEREMA A, REBELO AJ, BODI MB, ESLER KJ and MEIRE P (2017) Are ecosystem services adequately quantified? J. Appl. Ecol. 54 358-370. https://doi.org/10.1111/1365-2664.12696

CAPON SJ and PETTIT N (2018) Turquoise is the new green: Restoring and enhancing riparian function in the Anthropocene. Ecol. Manage. Restoration (Supplement S1). 19 44-53. https://doi. org/10.1111/emr.12326

COWDEN C, KOTZE DC, ELLERY WN and SIEBEN EJJ (2014) Assessment of the long-term response to rehabilitation of two wetlands in KwaZulu-Natal, South Africa. Afr. J. Aquat. Sci. 39 237-247. https://doi.org/10.2989/16085914.2014.954518

FENNESSY MS, JACOBS AD and KENTULA ME (2004) Review of rapid methods for assessing wetland condition. EPA/620/R-04/009. US Environmental Protection Agency, Washington, DC.

FISHER B, TURNER RK and MORLING P (2009) Defining and classifying ecosystem services for decision making. Ecol. Econ. 68 (3) 643-653. https://doi.org/10.1016/j.ecolecon.2008.09.014

HRUBY T, RICHTER K, FUERSTENBERG B and MURPHY M (2011) Calculating Credits and Debits for Compensatory Mitigation in Wetlands of Western Washington. Shorelands and Environmental Assistance Program, Washington State Department of Ecology, Olympia, Washington.

IPBES (Intergovernmental Science-Policy Platform on Biodiversity and Ecosystem Services) (2017) Update on the classification of nature's contributions to people by the Intergovernmental Science-Policy Platform on Biodiversity and Ecosystem Services. 7-10 March 2017. IPBES, Bonn.

KOTZE D, MACFARLANE D, EDWARDS R, MANDER M, COLLINS N, TEXEIRA-LEITE A, LAGESSE J, PRINGLE C, MARNEWECK G, BATCHELOR A and LINDLEY D (2020) WET-EcoServices Version 2.0: A technique for rapidly assessing ecosystem services supplied by wetlands and riparian areas. WRC Report No. TT 833/20. Water Research Commission, Pretoria, South Africa.

KOTZE DC, MARNEWECK GC, BATCHELOR AL, LINDLEY DS and COLLINS NB (2008) WET-EcoServices: A technique for rapidly assessing ecosystem services supplied by wetlands. WRC Report No TT 339/09. Water Research Commission, Pretoria.

KOTZE D C, TERERAI F and GRUNDLING P-L (2018) Assessing, with limited resources, the ecological outcomes of wetland restoration: a South African case. Restoration Ecol. 27 495-503. https://doi.org/ 10.1111/rec.12891

LIQUETE C, CID N, LANZANOVA D, GRIZZETTI B and REYNAUD A (2016) Perspectives on the link between ecosystem services and biodiversity: The assessment of the nursery function. Ecol. Indic. 63 249-257. https://doi.org/10.1016/j.ecolind.2015.11.058

MCINNES RJ and EVERARD M (2017) Rapid Assessment of Wetland Ecosystem Services (RAWES): An example from Colombo, Sri Lanka. Ecosyst. Services. 25 89-105. https://doi.org/10.1016/j.ecoser. 2017.03.024

MEA (Millennium Ecosystem Assessment) (2005) Ecosystems and Human Well-being: Synthesis. Island Press, Washington DC.

NAMAALWA S, VAN DAM AA, FUNK A, AJIE GS and KAGGWA RC (2013) A characterization of the drivers, pressures, ecosystem functions and services of Namatala wetland, Uganda. Environ. Sci. Polic. 34 44-57. https://doi.org/10.1016/j.envsci.2013.01.002

NRC (National Research Council) (2002) Riparian Areas: Functions and Strategies for Management. Committee on Riparian Zone Functioning and Strategies for Management. National Academy Press, Washington, DC, USA. 
REBELO O, JOHNSTON L-M, HEIN R, WEIGELHOFER T, DHAEYER G, KONE T and COOLS BJ (2013) Challenges to the integration of wetlands into IWRM: the case of the Inner Niger Delta (Mali) and the Lobau Floodplain (Austria). Environ. Sci. Polic. 34 58-68. https://doi.org/10.1016/j.envsci.2012.11.002

RSA (Republic of South Africa) National Water Act. Act No. 36 of 1998 Government Gazette 19182. Government Printer, Cape Town.

ROUNTREE MW, MALAN HL and WESTON BC (2013) Manual for the Rapid Ecological Reserve Determination of Inland Wetlands (Version 2.0). Joint Department of Water Affairs/Water Research Commission Study. WRC Report No. 1788/1/13. Water Research Commission, Pretoria.

SANBI (South African National Biodiversity Institute) (2013) Factsheet on ecological infrastructure. August 2013. South African National Biodiversity Institute, Pretoria.

SANBI (South African National Biodiversity Institute) and DWS (Department of Water and Sanitation) (2016) WETLAND OFFSETS: A Best Practice Guideline for South Africa. Report to the Water Research Commission. Report compiled by Macfarlane D, Holness SD, Von Hase A, Brownlie S, Dini JA And Kilian V. WRC Report No. TT 660/16. Water Research Commission, Pretoria.
SULLIVAN CA, MACFARLANE D, DICKENS C, MANDER M, BONJEAN M, TEIXEIRA-LEITE A and PRINGLE C (2008) Keeping the benefits flowing and growing: quantifying benefits of wetlands in the upper Orange/Senqu basin. Report to NeWater, a project funded under the Sixth Research Framework of the European Union. Institute of Natural Resources, Pietermaritzburg. TEEB (The Economics of Ecosystems and Biodiversity) (2010) The Economics of Ecosystems and Biodiversity: Ecological and Economic Foundations. Editor: Kumar P. Earthscan, London and Washington. VILLA F, BAGSTAD KJ, VOIGT B, JOHNSON GW, PORTELA R, HONZÁK M and BATKER D (2014) A methodology for adaptable and robust ecosystem services assessment. PLoS ONE. 9 (3) e91001. https://doi.org/10.1371/journal.pone.0091001

WEI H, FAN W, WANG X, LU N, DONG X, ZHAO Y, YA X and ZHAO Y (2017) Integrating supply and social demand in ecosystem services assessment: A review. Ecosyst. Services. 25 15-27. https:// doi.org/10.1016/j.ecoser.2017.03.017 